Meta

Journal des tradlucteurs

Translators' Journal

\title{
Expanding Swahili Lexicon by Means of Bantu Languages
}

\section{Anita Macwilliam}

Volume 33, numéro 4, décembre 1988

Symposium AILA 1987, Sydney

URI : https://id.erudit.org/iderudit/004604ar

DOI : https://doi.org/10.7202/004604ar

Aller au sommaire du numéro

\section{Éditeur(s)}

Les Presses de l'Université de Montréal

\section{ISSN}

0026-0452 (imprimé)

1492-1421 (numérique)

Découvrir la revue

Citer cette note

Macwilliam, A. (1988). Expanding Swahili Lexicon by Means of Bantu

Languages. Meta, 33(4), 577-579. https://doi.org/10.7202/004604ar d'utilisation que vous pouvez consulter en ligne.

https://apropos.erudit.org/fr/usagers/politique-dutilisation/ 


\section{EXPANDING SWAHILI LEXICON BY MEANS OF BANTU LANGUAGES*}

During the past twelve years (at least) there have been many papers written with reference to coining new terms in Kiswahili - there is even a Manual on Coinage in Kiswahili (Ohly 1982). All of these are valuable and lay out many different theories which run the gamut from using only internal Kiswahili sources (Temu 1979-1984) to using Internationalisms (Kiingi 1984) to a combination of both (Bakita 1978, Khamisi 1980, Mdee 1981, 1985, MacWilliam 1986)

A few general remarks about languages may not be amiss in order to lay the groundwork for some practical applications of the theory.

First of all, every language has in its lexicon all words necessary for the life of a people. Kiswahili as a Bantu language has at its disposal all the vocabulary necessary for people to live their lives. In Kiswahili we have words and structures to express daily existence, all our emotions and needs. In the new monolingual Kiswahili dictionary there are only about 13000 entries. There is no dictionary which lists all items in the lexicon of a language. And we know that there are many more Kiswahili words waiting to be recorded (conservative estimates place thern at 30000-50 000).

Secondly, every language, given time and expertise, can incorporate terms for new concepts through its own internal resources. In Kiswahili this has been done and is still being done. For example we have:

msikwao min asiye na kwao

person having no home $=$ vagrant

vilia vitu vya kulia chakula

things for eating food = cutlery

pembekali pembe + kaly

corner + sharp

$=$ acute angle

Thirdly, the closer or nearer the people of the world come together and the more interchange there is, the more cultural and technological concepts im- pinge upon the worldview and ideas of a people. The onslaught of the mass media (newspapers, magazines, radio, films, TV - satellite communications) bring new ideas, new concepts, new technology and news into our countries, villages and homes in a very short time. We have many examples of this - the news of the Mexican earthquake was on the Dar es Salaam news broadcasts within a few hours, the famine in Ethiopia, etc. So we are bombarbed by all types of things brought about by various technological advances. So whether we like it or not, we are changed, sometimes it seems for the better, sometimes for the worse. And this bombardment is accelerating every day.

Going back to the second fact, I said that given time and expertise a language can incorporate terms for new concepts from its own internal resources. The expertise is here in Tanzania. We have experts in Kiswahili, linguistics and in most of the disciplines. However, time is not on our side. Mwalimu Nyerere once said "we must run while they walk" (talk to students at Tabora school 196 ?). He was speaking of progress in general. However, we can use his words as a slogan to encourage us in our work of coining lexicon and terms. This is more imperative when we are speaking of new concepts etc. especially in the fields of technology and science. Therefore we need to run to catch up. The catching up is not just in the techniques, processes and scientific methods. We must also run in finding suitable terms for all of these concepts.

And this is precisely where I would like to look at the ways in which we borrow. This paper is going to concentrate only on one of the ways cited by the Language Standardization Committee :
a) Kiswahili itself
b) Bantu languages of Africa
c) other African languages
d) other languages

I am addressing myself to b) Bantu languages of Africa with an emphasis on Tanzanian Bantu languages.

To my mind there seem to be primarily only two ways to do this :

i) haphazardly

ii) systematically 
In going over the terms published by the Kiswahili Council, I found that terms were borrowed from 27 languages, $5 \mathrm{Kiswahili} \mathrm{dialects} \mathrm{and} \mathrm{four} \mathrm{zones} \mathrm{of} \mathrm{the}$ country. This led me to ask why only these languages, when there are more than 120 languages in Tanzania alone?

I realized from working on the EnglishKiswahili dictionary that the terms borrowed are often dependent on the people working on the word list or dictionary. For example, at present in the dictionary section, the members are composed of two people from Buhaya, one from Uchaga, one from Upare and one from Canada (who has a smattering of Kikuria and Kikwaya). When we find that there is a term missing, it is often supplied from Kihaya, $\mathrm{Ki}$ chaga or Kipare. I believe that this is the general trend. Apart from being completely unscientific, it can and does lead to problems. A term must relate to only one concept and each concept should have only one term. Secondly related terms usually show some affinity.

For example in the Geography terms (Tafsiri Sanifu \#3) we have:

$\begin{array}{lll}\text { English } & \text { Swahili } & \text { (horrowed from) } \\ \text { confluence } & \text { ndagano } & \text { (Kimwera) } \\ \text { confluent } & \text { kipera } & \text { (Kingoni) }\end{array}$

The meaning of the English terms are similar, one a noun, the other its adjective :

the confluence of the rivers...

the confluent river...

In Kiswahili we would be saying :

ndagano ya mito.. mto kipera...

It may be that there is some relationship structurally between ndagano and kipera - but it escapes me.

Another example (again from Geography) :

English Swahili (borrowed from)

boulder shiganga/ma- (Kisukuma)

boulder beds -

boulder clay -

boulder rock shiganga/ma- (Kisukuma)

hardpan kiganga/vi- (Kihehe)

If "hardpan" is made up of the same material as "boulder" then "kiganga" may be an acceptable form. However are "boulder" and "boulder rocks" synonyms or different terms ? If the latter, then Kiswahili must also distinguish. "Boulder clay" is not in the list of terms presented by Bakita. Will students in Tanzania only learn Geography of Africa or will they, at some time, also be exposed to Geography about other areas of the world ? Terminology is not a shortterm goal - only concerned with what is of immediate use for primary school texts. We should be developing full sets of terminologies, using the International Decimal Classification. There should be no problem with the idea that we have terms which have not been inserted into textbooks yet. They will be, and will be followed more easily if the foundations have been laid at the primary and secondary levels.

But there is more to life than science and technology. Some people earn their living in esoteric disciplines like bio-chemistry, nuclear physics, computer engineering, etc. The majority, however, work at such fundamental things as farming, fishing, hunting, carpentry, mechanics, etc. It is in these areas that I feel we have a fertile field for coining, borrowing from the other Bantu languages.

Each ethnic group in Tanzania has its own cultural matrix-traditional ways of living but also traditional ways of earning a living. We have readily available examples, the banana culture among the Wahaya, Wachaga and Wanyskyusa is a case in point. Bananas are not just "bananas" - there is a complete semantic and lexical field surrounding "bananas" (Chuwa 1985). Apart from that, these people are coffee growers. They have been for many years. Again, as with "banana", there is a wide ranging vocabulary connected with the cultivation of coffee. The Wasukuma have been growing cotton, probably longer than most other groups in Tanzania. Kisukuma has many terms for this type of agriculture - there are specific terms for the obligatory weeding times, etc. My contention is that now is the time to put into practice all the theory we have talked about these long years. It means work and hard work but it can be done. The idea of gathering vocabulary can be very tedious, especially if you are trying to get as many words as possible (Khamisi 1986a).

However, what I propose is that we concentrate on various work areas. That is, language and cultural officers who are in the field, be asked to write up a short report on the principal traditional means of livelihood of a particular group. For example, the Wakuria are primarily pastoralists - so let us not concentrate on maize growing among them but rather on cattle culture and its terms. The honeygatherers of Tabora - the farmers of Ukara who have a long tradition of crop-rotation, the Sonjo with their irrigation schemes are all fertile fields for research.

From these reports, experts in the subject field be asked to draw up a classified vocabulary of terms used in that particular field (Tumbo 1982). These lists then would be the beginnings of gathering raw data for filling lexical gaps.

An example of this type is Mtesigwa's M.A. Thesis "Ethnolects as a Source of Swahili Terms : The Case of Kikerewe Fisheries Terminology" (1982).

His thesis shows clearly that there are lexical gaps in Swahili fishing terminology. The reason for this is obvious, the Waswahili are a coastal people whose fishing is ocean fishing. The Wakerewe are people of the lake (Victoria) who fish fresh waters. Therefore many terms used by the Wakerewe are either not known in Swahili or are rendered by a descriptive phrase.

Would it not be in the interest of the fishing industry to gather terms from the lake fishermen and use them to fill in the gaps in Kiswahili fishing terminology? 
We don't need written theses. What we need is the lexicon of ordinary life - words from rice growers, hunters, honey gatherers, those with traditional irrigation schemes, crop-rotation and a tradition of fertilizing fields.

Recently we were looking for the word "scree" - it wasn't available in the Swahili word stock. But a trip to the Usambara or Kilimanjaro area would yield names for different types of soil and in all probability a word for "scree" would be among them

Expensive equipment is not the first priority for this work. The first priority is sustained cooperation among all our institutions. Secondly, people with a real interest in the modernization and growth of Kiswahili. Our tools are still paper and pencil. Once that is in place, we can begin to talk about such technical aids as computers, etc.

What will be the results? Hopefully a word bank in various ethnolects for a wide range of subjects. This will be and can be the raw material from which scholars can draw in order to build up good Kiswahili terminologies, rooted in Bantu, conforming to Swahili language structures.

ANITA MaCWILliam Institute of Kiswahili Research Dar es Salaam, Tanzania

Note

- Talk given at Workshop of National Kiswahili Council, Dar es Salaam, Tanzania, May 1986.

\section{REFERENCES}

AKIKA, H. (1983) : "Ukuzaji na Uendelezaji wa Msamiati wa Kiswahili" (Growth and Progress of Kiswahili Vocabulary), Makala za Semina ya Kimataifa ya Waandishi wa Kiswahili I Lugha ya Kiswahili, Taasisi ya Uchunguzi wa Kiswahili, Dar es Salaam. (Papers of the International Seminar of Kiswahili Writers, vol. I, Kiswahili Language.)

BAKITA (1978) : Tafsiri Sanifu (Standard Translations), $n^{\circ} 3$, National Kiswahili Council, Dar es Salaam.

BAKITA (1980) : Tafsiri Sanifu, no 4

CHUWA, A. (1985) : Symbolism Among the Wachaga, Unpub. M.A. Thesis, University of Lancaster.

KHAMISI, A.M. (1980) : "Language Planning Processes in Tanzania", in Proceedings of the Summer Institute on Language Planning, Mysore.

KHAMISI, A.M. (1986) : "Current Trends in Language Standardization in Tanzania".

KIANGO, J.G. (1983) : "Uundaji wa Msamiati Mpya katika Kiswahili : Zoezi lenye njia mbalimbali", Semina ya TUKI (Coining new Kiswahili vocabulary - many different ways, Seminar of Institute of Kiswahili Research).
KIINGI, K.B. (1984) : "The Lexical Extension of Kiswahili as Conceived by the Institute of Kiswahili Research", Unpub.

MacWILLIAM, A. (1986) : "Some Thoughts on Translation of Scientific Terminology", Kiswahili, vol. 52.

MDEE, J.S. (1982) : "Matatizo ya Kuunda Istilahi/ Maneno Mapya kama Yalivyojitokeza Katika Kiswahili" (Problems of Coining Terminologies/ New Vocabulary as evidenced in Kiswahili), Seminar IKR.

MHINA, G.A. (n.d.) : "Towards Developing Technical Swahili".

NKUDE, J.J. (1983) : "Mwanasayansi, Istilahi na Utengenezaji wa Kamusi" (Scientists, Terminologies and Compilation of Dictionaries), Dar es Salaam, MKUI, IKR.

MTESIGWA, P.C.K. (1983) : Ethnolects as a Source of Swahili Terms: The Case of Kikerewe Fisheries Terminology, Unpub. M.A. Thesis, University of Dar es Salaam.

OHLY, R. (1982) : A Short Manual of Coinage in Kiswahili, EACROTANAL, Zanzibar

TEMU, C.W. (1974) : "Swahili Phonetical Word Building Resources", Kiswahili, vol. 44/1.

TEMU, C.W. (1984) : "Kiswahili Terminology Principles Adopted for the Enrichment of the Kiswahili Language", in Kiswahili, vol. 51.

TUMBO, Z. (1982) : "Towards a Systematic Terminology Development", in Kiswahili, vol. $49 / 1$. 